\title{
Editorial PSA
}

\section{From Mahidol University Journal of Pharmaceutical Sciences to Pharmaceutical Sciences Asia, From MUJPS to PSA}

Assoc. Prof. Mullika Traidej

Chomnawang,

B.S. (Pharmacy)

Ph.D. (Microbiology)

Editor-in-Chief
Mahidol University Journal of Pharmaceutical Sciences (MUJPS) was first published in 1974 by the Faculty of Pharmacy, Mahidol University, Thailand. In 2017, the journal was renamed the Pharmaceutical Sciences Asia (PSA) journal. The PSA journal is an international peer-reviewed journal in English and committed to the timely publication of innovative articles and reviews. Since 2021, this journal is currently available only in an electronic format on the website: https://pharmacy.mahidol.ac.th/journal/. In addition, a doubleblinded peer-review system has been implemented via an online system to ensure high-quality work. To accelerate the publication process, the PSA journal has increased the issue numbers per year from quarter to six issues since January, 2021.

The PSA journal aims to disseminate knowledge, provide a learned reference in the field, and establish communication channels between academic and research experts, policy makers, and executives in industry and investment institutions. The journal publishes original research articles, review articles, and scientific commentaries on all aspects of the pharmaceutical sciences and related fields in health professions and medicine. More specifically, the journal publishes research on 4 major areas of pharmaceutical sciences and related disciplines:

- Biopharmaceutical Sciences

- Pharmaceutical Sciences and Technology

- Pharmaceutical Chemistry and Phytochemistry

- Clinical Pharmacy and Social Administrative Pharmacy

The quality of researches published in the PSA journal is of high standard reflecting by its citation in the SCOPUS database. As of 2021, the number of citations is 266. The PSA journal is also indexed in Scifinder, Rikenbase, Worldcat, ASEAN Citation Index (ACI) and Thailand Citation Index (TCI).

In the year of 2022, the PSA journal will continue improving the quality of the journal as our goal is to meet high international standard. 


\section{Journal metrics}

- In 2020, the ranking of the PSA journal was in the $3^{\text {rd }}$ quartile of Scopus database. The CiteScore was 0.4 , SJR 0.144 and SNIP 0.378 .
- The PSA journal is ranked 52/67 in Pharmacology, Toxicology and Pharmaceutics and 204/246 in the subject of Pharmacology (medical) in 2020.

- Top 5 cited articles of the PSA published since 2016:

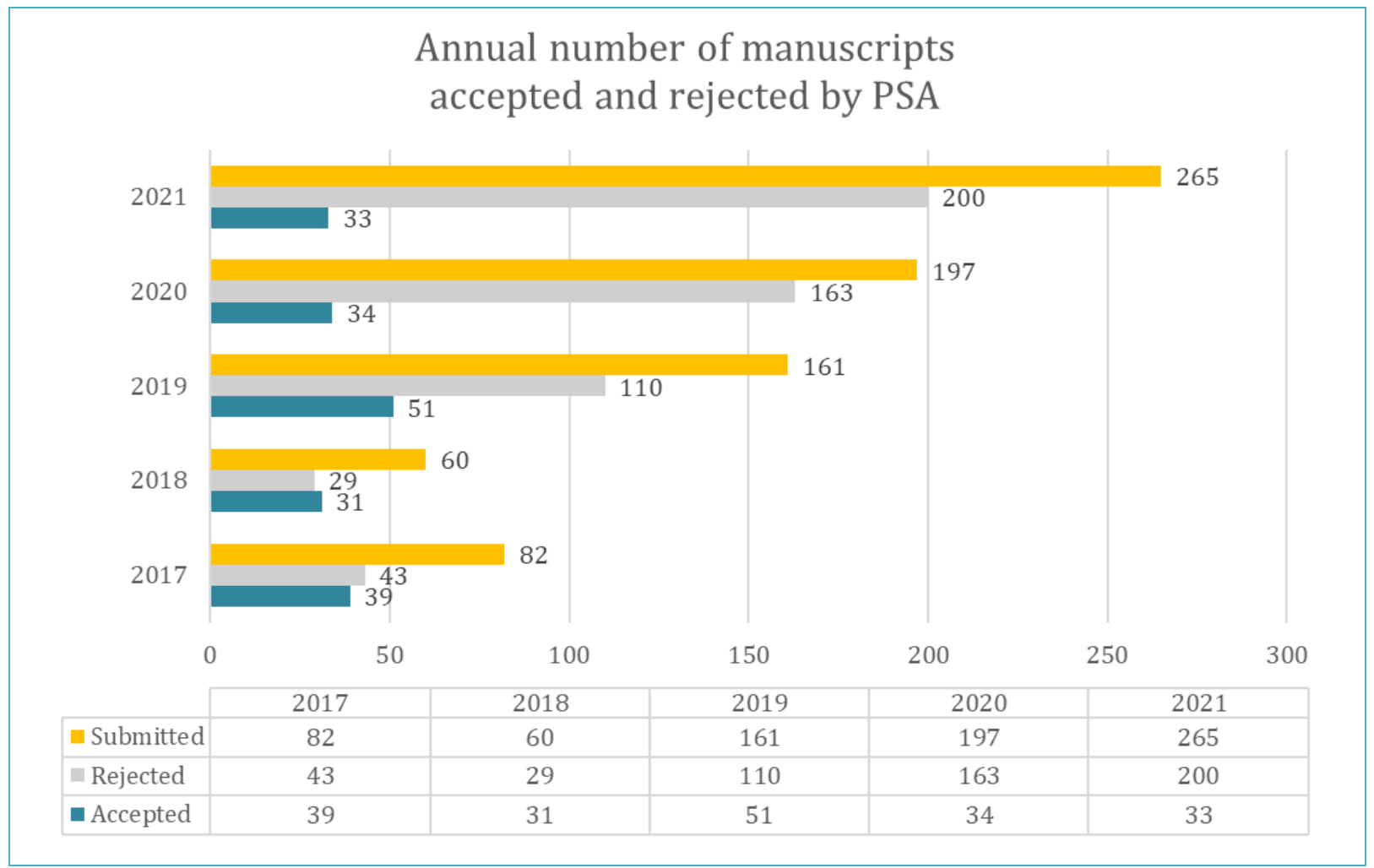

Figure 1. Annual number of manuscripts accepted and rejected by PSA

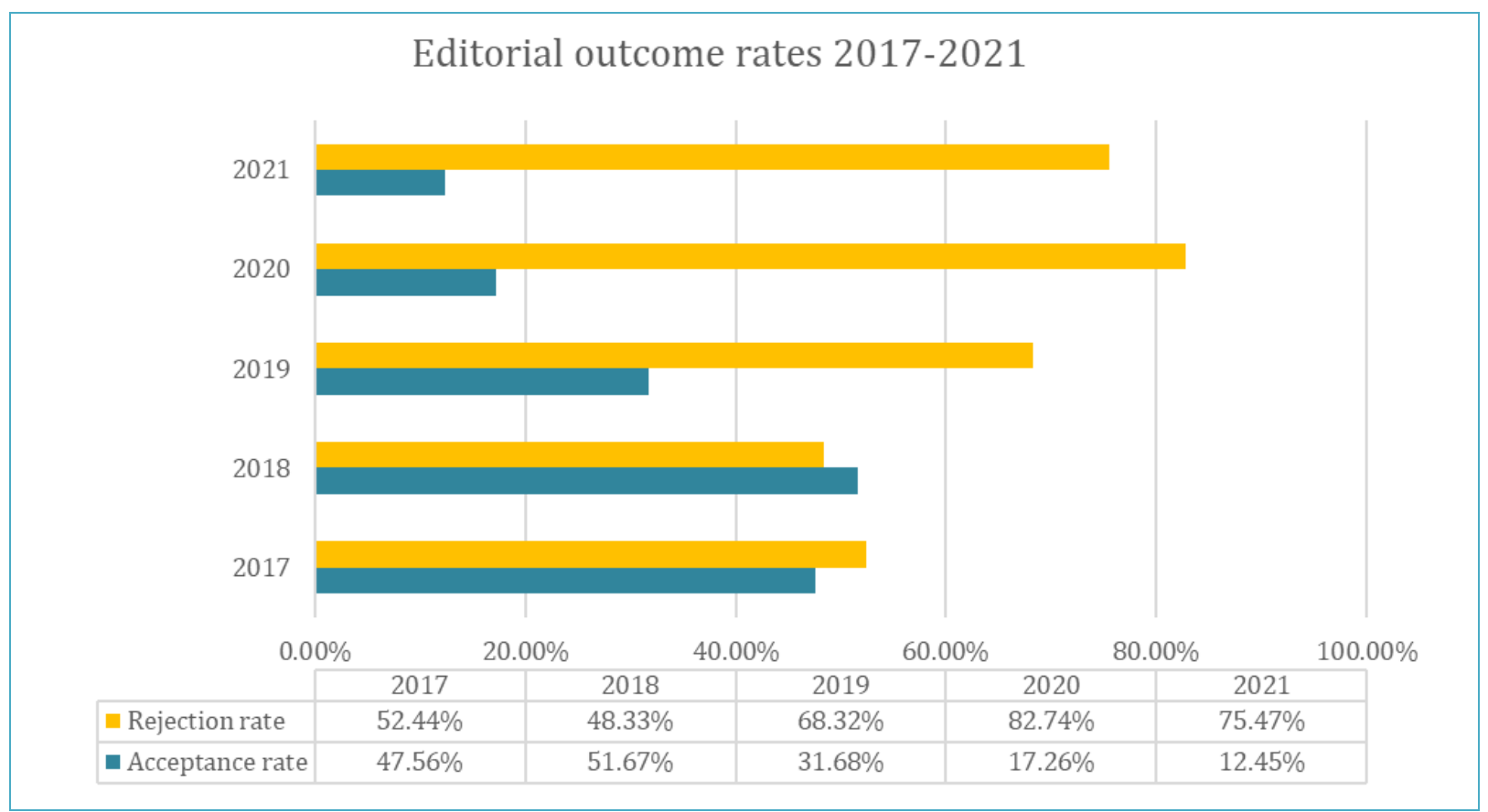

Figure 2. Editorial outcomes rates 2017-2021 
Table 1. The top countries of authors from which articles were accepted to be published in PSA (accessed on December 30, 2021)

\begin{tabular}{|c|c|c|c|c|c|}
\hline \multirow[b]{2}{*}{ Country } & \multicolumn{5}{|c|}{ Numbers of articles } \\
\hline & 2017 & 2018 & 2019 & 2020 & 2021 \\
\hline Thailand & 12 & 13 & 17 & 23 & 16 \\
\hline Viet Nam & 6 & 13 & 8 & 2 & 4 \\
\hline Indonesia & & & 4 & 7 & 5 \\
\hline Philippines & 2 & & 2 & 2 & \\
\hline India & 2 & 1 & 1 & & \\
\hline France & 1 & & & 1 & \\
\hline Myanmar & & & 1 & 1 & \\
\hline Egypt & & & 1 & & 2 \\
\hline Ethiopia & & 1 & & & \\
\hline Germany & & & & 1 & \\
\hline Japan & & 1 & & & \\
\hline Laos & & & 1 & & \\
\hline Malaysia & & & 1 & & 2 \\
\hline Netherlands & & & & 1 & \\
\hline Nigeria & & & 1 & & \\
\hline South Korea & & 1 & & & \\
\hline Sri Lanka & 1 & & & & 1 \\
\hline Switzerland & & & 1 & & \\
\hline Syrian Arab Republic & & & & 1 & \\
\hline United Arab Emirates & & & & 1 & \\
\hline Sweden & & & & & 1 \\
\hline Iraq & & & & & 1 \\
\hline Ghana & & & & & 1 \\
\hline USA & & & & & 1 \\
\hline Brunei Darussalem & & & & & 1 \\
\hline
\end{tabular}

Table 2. The most cited PSA publications (accessed on December 30, 2021)

\begin{tabular}{|c|c|c|c|c|c|c|}
\hline Article title & Year & 2019 & 2020 & 2021 & $>2021$ & Total \\
\hline $\begin{array}{l}\text { Preparation of nanoemulsions by phase inversion temperature } \\
\text { (PIT) method } \\
\text { Jintapattanakit A }\end{array}$ & 2018 & 2 & 6 & 7 & 1 & 16 \\
\hline $\begin{array}{l}\text { Use of modified tapioca starches as pharmaceutical excipients } \\
\text { Charoenthai N, Sanga-ngam T, Puttipipatkhachorn } S\end{array}$ & 2018 & 2 & 2 & 2 & & 6 \\
\hline $\begin{array}{l}\text { Cost effective paper-based colorimetric devices for a simple } \\
\text { assay of dopamine in pharmaceutical formulations using } \\
3,3^{\prime}, 5,5 \text { '-tetramethylbenzidine- silver nitrate as a chromogenic } \\
\text { reagent } \\
\text { Manmana Y, Chutvirasakul B, Suntornsuk L, Nuchtavorn N }\end{array}$ & 2019 & & 3 & 2 & & 5 \\
\hline $\begin{array}{l}\text { Factors affecting micropropagation of Cannabis sativa L.: A } \\
\text { review } \\
\text { Boonsnongcheep P, Pongkitwitoon B }\end{array}$ & 2020 & & & 4 & & 4 \\
\hline $\begin{array}{l}\text { Comparative in vitro activity of sitafloxacin against multidrug- } \\
\text { resistant and carbapenem-resistant Acinetobacter baumannii } \\
\text { clinical isolates in Thailand } \\
\text { Paiboonvong T, Rodjun V, Houngsaitong J, Chomnawang M, } \\
\text { Montakantikul P, Chulavatnatol S }\end{array}$ & 2020 & & 2 & 1 & & 3 \\
\hline
\end{tabular}


In addition, as an Editor-in-Chief of the PSA journal, I would like to express my gratitude to all Editorial board members, issue editors, and managing editors. Sincere thanks go to all reviewers for their insightful comments on the manuscripts. Last but not least, I would also like to thank all authors and readers for their continuous trust and support. 